\title{
Creating and Supporting a Harassment- and Assault-Free Field School
}

\author{
Carol E. Colaninno e, Shawn P. Lambert, Emily L. Beahm, and Carl G. Drexler
}

\section{ABSTRACT}

Given the hierarchical nature and structure of field schools, enrolled students are particularly susceptible to harassment and assault. In 2018 , the National Academies of Sciences, Engineering, and Medicine (NASEM) released recommendations to help prevent sexual harassment and assault of women in academia. Although these recommendations are specific to higher education and exclusive to women, some can be modified and applied to the context of archaeological field schools. We review the NASEM's recommendations, with particular attention to those applicable to the field school setting, and provide suggestions for making field schools safer and more inclusive learning environments for all students. Although we present recommendations for practices that can be implemented at field schools, additional research is needed to understand how sexual harassment occurs at field schools and how the implementation of these recommendations can make learning safer.

Keywords: field schools, sexual harassment and assault, means of prevention

Dada la naturaleza jerárquica y la estructura de las escuelas de campo, los estudiantes matriculados son particularmente susceptibles al acoso y la agresión. En 2018, las Academias Nacionales de Ciencias, Ingeniería y Medicina (NASEM, por sus siglas en inglés) publico recomendaciones para ayudar a prevenir el acoso sexual y el asalto de mujeres en la academia. Aunque estas recomendaciones son específicas para la educación superior y exclusivas para las mujeres, algunas pueden modificarse y aplicarse al contexto de las escuelas de campo arqueológico. Revisamos las recomendaciones de NASEM con especial atención a las aplicables al entorno de las escuelas de campo y brindamos sugerencias para hacer que las escuelas de campo sean entornos de aprendizaje mas seguros e inclusivos para todos los estudiantes. Aunque presentamos recomendaciones para prácticas que se pueden implementar en las escuelas de campo, se necesita investigación adicional para comprender como ocurre el acoso sexual en las escuelas de campo y como la implementación de estas recomendaciones puede hacer que el aprendizaje sea mas seguro para todos los estudiantes.

Palabras clave: escuelas de campo, acooso sexual y agresión, medios de prevención

Educational scholars have recognized the positive learning outcomes that students achieve by participating in field-based research (Cartrette and Melroe-Lehrman 2012; Cooper et al. 2019; Flaherty et al. 2017; Munge et al. 2018; National Research Council 2014; Sheppard et al. 2010). Through such experiences, students show increases in their motivation to learn (Jacobson et al. 2015) and perceptions of their abilities to succeed in their field of study (Graham et al. 2013). Field-based learning helps students achieve cognitive and metacognitive gains and competencies that move them from having a novice to an expert understanding (Mogk and Goodwin 2012; Richards et al. 2012; Whitmeyer and Mogk 2009).

In the United States, field-based training has long been a primary educational component for students pursuing a bachelor's degree in anthropology specializing in archaeology (Baxter 2009:11; Brookes 2008; Mytum 2012; Perry 2004; Walker and Saitta 2002). Undergraduate and graduate archaeological field learning includes a participatory course-referred to within the discipline as a field school-where students learn practical field methods. Field schools are often the first opportunity for aspiring archaeologists to apply and practice the concepts and methods they learn during their coursework. For many students, their field school is a formative experience confirming their intent to pursue archaeology as a career. For others, field school may be a prohibitive requirement, given the costs and time commitment, or a course that deters students from a career in archaeology (Heath-Stout and Hannigan 2020).

Although many have noted the positive gains that students experience from participation in field-based research, recent studies demonstrate that field experiences and research can come with negative consequences (Clancy et al. 2014; Meyers et al. 2018; Nelson et al. 2017; VanDerwarker et al. 2018). In archaeology specifically, a recent study documented high rates of sexual harassment and assault among those conducting field research. Of respondents to a recent survey administered to archaeologists 
conducting research in the southeastern United States, 66\% reported sexual harassment and 13\% reported sexual assault (Meyers et al. 2018). Although not exclusive to field school students, these numbers-and others-suggest that instances of sexual harassment and assault are common and that student trainees are frequently subjected to such treatment (Clancy et al. 2014). Aspiring archaeologists may experience their first occurrence of sexual harassment, assault, and violence as undergraduate or graduate students enrolled at field school.

Scholars have suggested policies and procedures that institutions, organizations, and supervisors can implement to help prevent sexual harassment and assault in academia, although not exclusive to the setting of field schools (NASEM 2018). In this article, we review some of these policies with attention toward those that can be actualized in a field school setting. Although we make initial suggestions for how field school directors can support harassment- and assault-free field schools, these suggestions are just the first step toward understanding evidence-based best practices that can prevent sexual harassment and assault. Foundational research is greatly needed to document how these policy and procedural changes affect supervisory roles, student learning, and the overall nature of the field school climate and culture.

Throughout the article, we use the phrase "safe and inclusive field school environment" with the assertion that an environment in which an individual experiences sexual harassment, assault, or violence is unsafe and excludes a student from learning. A safe and inclusive learning environment is one in which a student does not feel at risk of or exposed to harassing, assaulting, or violent behavior, and they feel able to learn.

\section{THE SETTING: FIELD SCHOOLS}

Since the inception of archaeological education, institutions of higher education have stressed the need for students to acquire practical skills in field methodologies by requiring students to complete a field school to receive a bachelor's degree in anthropology with a specialization in archaeology (Aitchison 2004; Baxter 2009; Gifford and Morris 1985). This practice continues to this day. The educational structure of field schools varies among university programs and other organizations offering field schools (Mytum 2012). Generally, field schools consist of four to eight weeks of sustained field training that may include instruction and practice in excavation techniques, archaeological survey, fieldbased data collection, and data processing. Some field schools are generalized, while others are specialized, focusing on the recovery and analysis of a specific data class. It should be noted that students must pay tuition and course fees to enroll in a field school and gain the corresponding experiences.

The location of field school instruction also varies, although field schools are held in areas of archaeological interest. Even within the United States, field schools may be in remote locales where students do not have basic amenities of modern-day life, such as internet connection, cellular phone service, running water, or access to transportation. Others are in urbanized settings where living conditions are similar to a modern college-student lifestyle. At some field schools, living arrangements can be residential, with students spending the entirety of their training away from their home and college campus. Others do not require students to live at the field school. Instead, students reside in their own homes or dorms throughout the duration of the course.

Field schools are hierarchical, usually led by one or more faculty or project director. In cases where the field school is associated with a university program, the field school director may not be full-time faculty at the institution offering the field school. Field schools vary in the number of enrolled students. Some have only a handful of student trainees, while others can have over 20 students. Often, graduate students aid the field director and have varying levels of responsibility. Some teach and provide supervisory support, whereas others manage the field school. Generally, field directors have the ultimate authority in research and instruction. Field directors may require students to receive instructions from them when they encounter anything significant, and they will review students' work before allowing them to proceed with excavations.

Despite the long-standing tradition of field schools as an institution and rite of passage for archaeological education, there has been little empirical research into field school pedagogy (but see Baxter 2009; Brookes 2008; Everill 2015; Lightfoot 2009; Mytum, ed. 2012; Perry 2004). Currently, what has been written neglects to address how faculty can structure their field schools to help prevent harassing and assaulting behaviors and promote educational equality for all students.

\section{THE CONTEXT OF SEXUAL HARASSMENT, ASSAULT, AND VIOLENCE}

Sexual harassment, assault, and violence are a documented, persistent issue faced by both women and men, historically marginalized individuals, those who are diverse learners, and members of the LGBTQ+ community in academia (Berdahl and Moore 2006; Brown et al. 2017; Garvey et al. 2017; Gay-Antaki and Liverman 2018; Kalof et al. 2001; NASEM 2018; Rankin 2005; Settles et al. 2016). Sexual harassment is a form of gender-based discrimination that is both a legal term (Dobbin and Kelly 2007; USEEOC 2019) and a term to describe a spectrum of verbal and nonverbal actions with negative psychological and health consequences to those subjected to these behaviors (NASEM 2018). Sexual harassment encompasses three types of behaviors that may or may not co-occur: gender harassment, unwanted sexual attention, and sexual coercion (Fitzgerald et al. 1995).

Gender harassment comprises a suite of nonsexualized acts that persecute an individual based on their gender, and it includes gender-based "put-downs," inappropriate comments, and offensive remarks, among other acts (Leskinen et al. 2011). Unwanted sexual attention occurs when an individual experiences unreciprocated sexual advances. Sexual coercion includes sexual attention and the conditioning of employment or educational opportunities upon sexual cooperation (NASEM 2018). Unwanted sexual attention and sexual coercion aim to persuade an individual to cooperate with sexual acts, whereas gender harassment does not, although gender harassment is the most common form of harassment (Fitzgerald et al. 1995). 
Sexual violence is any act or attempted act to obtain sexual contact by means of force, aggression, or coercion, including rape. Sexual assault is a form of sexual violence that occurs when an individual touches another person in a sexual nature without that person's consent or when a person is physically forced into a sexual act against their will (Fedina et al. 2018). Although sexual assault and violence are less frequently reported compared to sexual harassment, these harmful acts continue to be an issue in higher education (Cortina et al. 1998; Tenbrunsel et al. 2019).

Although recent research has been directed toward understanding how women experience sexual harassment (NASEM 2018), men, non-gender-conforming, and nonbinary individuals also are subjected to sexual harassment and assault. It is important to note that individuals of color, those who are diverse learners, and those who do not fit traditional heteronormative roles encounter harassing and violent sexualized behavior more frequently than do majority white individuals conforming to traditional views of gender and sexuality in both academia and nonacademic workplaces (Berdahl and Moore 2006; Brown et al. 2017; Clancy et al. 2017; Gay-Antaki and Liverman 2018).

Research has shown the negative consequences that harassment and assault can have on those who experience such acts, both in terms of physical and mental health and academic performance and persistence (Aycock et al. 2019; Banyard et al. 2017; Brown et al. 2009; Chan et al. 2008; Potter et al. 2018; Settles et al. 2016). Students who experience sexual harassment, assault, and violence often struggle to maintain their GPA (Jordan et al. 2014), selfefficacy in their field of study (Aycock et al. 2019), and an adequate level of college performance (LeBlanc et al. 2014). The consequences of sexual harassment and assault are again felt when survivors face negative effects on their future career and educational potential (McLaughlin et al. 2017). Given the pervasiveness of sexual harassment, assault, and violence within the discipline of archaeology (Meyers et al. 2018; VanDerwarker et al. 2018), we may be losing students subjected to unsafe and unsupportive field schools prior to entering the field professionally (Muckle 2014).

\section{PREVENTING SEXUAL HARASSMENT AND ASSAULT: WHAT WE KNOW FROM OTHER FIELDS}

In 2018, the National Academies of Sciences, Engineering, and Medicine (NASEM) published Sexual Harassment of Women: Climate, Culture, and Consequences in Academic Sciences, Engineering, and Medicine. In this report, leading experts from multiple sectors undertook a review of how sexual harassment and assault affects women at all levels-including faculty, staff, and students - in the scientific, technical, engineering, and medical workforces (NASEM 2018). These experts reviewed current research on the extent to which women are subjected to sexual harassment and assault in various settings on college campuses; the extent to which sexual harassment and assault deleteriously affect how women experience recruitment, retention, and advancement in scientific, engineering, and medical careers; and the identification of practices and policies that support settings in which sexual harassment is prevented, reduced, and addressed when it occurs (NASEM 2018:17).

The NASEM defined five factors that create the conditions in which sexual harassment is likely to occur. It also presented 15 evidence-based recommendations for colleges and universities that, if implemented, may help to support safe and inclusive environments in higher education.

The five factors that tend to create conditions where sexual harassment and assault are more likely to occur are environments characterized by (1) a perceived tolerance for sexually inappropriate behavior, (2) a male-dominated work setting and a work setting where leadership is male dominated, (3) a power structure in organizations that are hierarchical with a strong dependency on those at higher levels in the hierarchy, (4) a focus on policy compliance to protect organizational liability, and (5) leadership that does not prioritize or intentionally focus on measures to reduce and eliminate inappropriate sexual behavior (NASEM 2018:3-4).

The NASEM's recommendations to prevent and reduce sexual harassment are intended for leaders of institutions of higher education, departments, research laboratories, professional societies, and lawmakers (NASEM 2018:5-12). Recommendations 1 through 10 are oriented toward practices that can be implemented at institutions of higher education, whereas recommendations 11 through 15 are related to legislative actions that state and federal governments and agencies should consider (NASEM 2018:9-12). We provide a paraphrased overview of recommendations 1 through 10 in Table 1. These recommendations have implications for how universities, colleges, departments, and field school directors should structure policies and practices to reduce and prevent sexual harassment and assault at their field sites. We stress that although these recommendations have implications for the ways we structure field schools, we must research both how directors implement these recommendations and how these recommendations affect students' safety as well as their perception of safety and their ability to learn (Colaninno 2019).

Overall, these recommendations center on creating an organizational climate and work environment in which sexually inappropriate behavior is not tolerated and in which those subjected to sexual harassment and assault are supported through the processes of reporting, investigation, and resolution. The report states that "the most potent predictor of sexual harassment is organizational climate-the degree to which those in the organization perceive that sexual harassment is or is not tolerated" (NASEM 2018:x). It is important to note that the NASEM directed these recommendations toward institutional leadership. Other scholars have reported similar recommendations or components of these recommendations as a means to support safe and inclusive field environments in anthropology, as well as other disciplines (Barthelemy et al. 2016; Clancy et al. 2014; Meyers et al. 2018; Nelson et al. 2017; St. John et al. 2016).

The five factors that create the conditions in which harassment is more likely to occur and the recommendations to reduce, prevent, and address inappropriate sexual behavior are relevant to the field school context. We review how these factors can apply to the context of a field school and suggest ways to actualize the NASEM recommendations to build and support safe and inclusive field schools for all students. 
Table 1. National Academies of Sciences, Engineering, and Medicine (NASEM) Evidence-Based Recommendations.

\section{NASEM Recommendations and Summary of Explanation}

1. Create diverse, inclusive, and respectful environments

Institutions of higher education should strive for greater gender and racial equity and create promotional pathways that reward the creation of inclusive environments. Training should not be viewed as a means to achieve compliance.

\section{Address gender harassment, the most common form of sexual harassment}

Institutions of higher education should provide considerable attention to practices and policies that prevent gender harassment.

\section{Address the climate and culture of sexual harassment and move beyond legal compliance}

Institutional leaders must engage with and listen to those who have been the target of sexual harassment. Institutional leaders must also work with the campus community to move beyond basic legal compliance.

\section{Improve transparency and accountability}

Institutions should have clear, accessible policies on sexual harassment that are consistent. They should be transparent with how sexual harassment incidents are handled, and they should be held accountable when exclusive and unsafe environments develop.

\section{Diffuse the hierarchical and dependent relationships between trainees and faculty}

Institutions should implement power-diffusing mechanisms, such as mentoring networks and/or committee-based advising, to reduce

hierarchical structures and the risk of sexual harassment.

\section{Provide support for those who are the target of sexual harassment and assault}

Institutions should support those who report incidents of sexual harassment and assault, and they should provide a means for those victimized to access support services.

\section{Strive for strong leadership that is diverse}

Institutional leadership should explicitly develop reduction and prevention of sexual harassment as a goal, and it should support leaders within the institution in their development of skills to prevent and recognize sexual harassment.

\section{Measure progress}

Institutions should evaluate and assess if their efforts to build safe and inclusive environments have worked among all populations they serve.

\section{Incentivize change}

Institutions should develop awards and apply for established awards that recognize safe and inclusive learning environments in higher education.

10. Encourage the involvement of professional societies and other organizations

Professional societies should have a role in helping to create cultural transformations that reduce and prevent sexual harassment, and they should help to facilitate research and training.

Note: Paraphrased version of recommendations 1 through 10 of 15 from NASEM 2018:5-9.

\section{THE FIVE FACTORS FOUND AMONG FIELD SCHOOLS}

Field schools can often be described by the five factors the NASEM identifies as conditions that allow sexual harassment to occur. This underscores the need for field school directors to implement policies intended to build safe and inclusive learning environments and support and protect students.

\section{A Perceived Tolerance for Sexually Inappropriate Behavior}

Although conversations about sexual harassment and assault in field-based research settings are becoming more common, many note that within our profession, there is a "culture of apathy" toward harassment and assault (Hays-Gilpin et al. 2019). Those with the authority and power to report inappropriate behavior may choose to look the other way, tolerate the behavior, or even participate in the behavior. Currently, we do not have the data to understand how those practicing archaeology chose to handle untoward behavior directed at students and colleagues. We know, however, that sexually inappropriate behavior does happen in archaeology (Collective Change 2019), and field school directors may do nothing to change this behavior when it occurs. The field school is often the first archaeological research experience for students, but it may also be the first time a student's concerns and reports of harassment and assault are intentionally ignored or unintentionally overlooked. Furthermore, future perpetrators of harassment may see that sexual harassment and assault are normal components of archaeological fieldwork, thereby perpetuating this culture of tolerance. People practicing archaeology may perceive that fieldwork and the field school are spaces where inappropriate behavior goes unnoticed.

\section{Males Dominate the Work Setting and Leadership Is Particularly Male Dominated}

Over the last few decades, women have surpassed men as the recipients of undergraduate and advanced degrees (Leslie et al. 2015). Despite this fact, disparities in gender equity remain with respect to academic leadership and tenure-track appointments (Ceci and Williams 2011; Clauset et al. 2015; Moss-Racusin et al. 2012). This holds true for archaeology (Goldstein et al. 2017; Jalbert 2019). Furthermore, as is the case with many disciplines with field-oriented research, archaeology holds an underlying perception-among the public and within the field-that archaeological fieldwork is conducted, investigated, and reported by men (Bardolph 2014; Bardolph and VanDerwarker 2016; Moser 2007). Fieldwork is often associated with masculinity and is tied to 
masculine values and behaviors (Moser 2007). Although the ratio of men to women directing field schools appears to be more balanced compared to years past (Diaz-Andreu and Sørensen 1998), the deep history and the continued perception of male dominance creates an environment in which males often hold or are perceived to hold power. Furthermore, the NASEM report notes that "environments that are no longer male dominated in gender ratio may still be male dominated in their work practices, culture, or behavioral expectations" (NASEM 2018:47).

\section{Power Structures Are Hierarchical with a Strong Dependency on Those at Higher Levels}

Field schools and much of archaeological fieldwork is organized in a hierarchical power structure-another characteristic of a work environment that can lead to the tolerance of sexual harassment and assault. For many field schools, field directors have the ultimate authority in research and instruction. Field school directors may delegate responsibilities to graduate students, interns, and others with prior experience, but for the most part, they have the ultimate authority in the field. The ultimate power that field school directors possess creates multiple issues related to sexual harassment and assault.

Field school directors have the ability to set the culture and climate of the field school. They can intentionally set the tone of the field school by talking to their students about respectful, professional field behavior; setting expectations for students, staff, and their behavior; and communicating how instances of sexual harassment and assault will be handled. Alternatively, they can ignore or even participate in inappropriate comments, laugh at gender-based and sexist jokes, and tolerate an environment in which certain students may feel uncomfortable or unwelcome.

Field school directors also have the authority to restrict who can access and learn certain techniques essential to archaeological field research. For example, only a select handful of trusted students may be taught how to use expensive equipment or help process technical data. This structure leads to field school directors and other supervisors singularly having the ability to provide learning opportunities to some students but not others. Furthermore, field directors have the power to make valued learning opportunities conditional upon student behavior. Clearly, the hierarchical structure of field schools can create power imbalances among all those involved-directors, staff, and students-which can lead to inappropriate behavior being overlooked, tolerated, or even encouraged.

\section{There Is a Focus on Policy Compliance}

Field school directors may primarily focus on implementing their home institution's Title IX sexual harassment and assault policies and training designed for students. Although Title IX sexual harassment training may be one of the most traditional and commonly employed mechanisms to prevent sexual harassment, research suggests that compliance-oriented trainings are ineffective (NASEM 2018:150). Research does suggest that students may learn more about sexual harassment and assault through these trainings (Moyer and Nath 1998), but they are unproductive preventative measures (Bingham and Scherer 2001). As a discipline, we currently do not have data on the number of field school directors who provide compliance-oriented policy reviews and training. As such, we currently do not know if directors focus on implementing sexual harassment and assault policies and trainings that are not necessarily effective.

\section{Leadership Does Not Prioritize or Intentionally Focus on Measures to Reduce and Eliminate Inappropriate Sexual Behavior}

Just as we do not know the frequency with which field school directors implement compliance-oriented policy trainings, we also do not understand how or if field school directors intentionally design a field-based learning environment that prevents and reduces the occurrence of inappropriate behavior. This issue may also be complicated by the fact that the overall field-school design structure may be strongly suggested or explicitly directed by the academic department or home institution. Again, further research is needed to understand if field school directors intentionally try to create a field school climate and culture in which professional behavior is expected and in which inappropriate behavior is not tolerated.

\section{IMPLEMENTING RECOMMENDATIONS AT FIELD SCHOOLS}

We reviewed the NASEM's recommendations 1 through 10, focusing on how they can be actualized in the context of a field school (Table 2). When we reviewed NASEM's recommendations, five overarching themes that are applicable to the field school setting became apparent. These include (1) preparation, (2) climate and culture, (3) supervisory hierarchies, (4) reporting mechanisms, and (5) support.

\section{Preparation}

Preparing to handle issues of sexual harassment and assault that may occur in a responsible, fair, and respectful way is a fundamental step toward prevention. Although compliance-oriented trainings are ineffective, bystander intervention training can be an important tool to help people respond to any experienced or witnessed inappropriate behavior (Coker et al. 2011, 2015; Holland et al. 2016). Bystander intervention training allows people within a community to see the specific role they can play in recognizing scenarios where harassment and assault are likely to occur. With this recognition, they are then able to intervene safely when these scenarios occur (Banyard et al. 2007). At a minimum, bystander intervention training can introduce students, staff, and directors to those situations where sexually inappropriate behavior is more prevalent (Banyard et al. 2007). This form of training should prepare field school directors, supervising staff, and students to respond appropriately to untoward behavior before such behaviors become problematic to the field school's learning environment. Furthermore, by requiring that they, their students, and staff take bystander intervention training, field directors set the tone that inappropriate sexual behaviors are not tolerated at their field schools-another critical aspect of building a safe and inclusive field school (NASEM 2018; Table 2). 
Table 2. Themes of NASEM Recommendations and Actionable Items.

\begin{tabular}{|c|c|c|}
\hline Theme & Associated Modified Recommendations & Actionable Item \\
\hline Preparation & $\begin{array}{l}\text { - Recommendation } 1 \mathrm{~d} \text { : Field directors should cater their } \\
\text { training to specific populations } \\
\text { - Recommendation 1e: Field directors should use training } \\
\text { approaches that develop interruption and intervening } \\
\text { skills }\end{array}$ & $\begin{array}{l}\text { - Participate in evidence-based training catered to supervisors of } \\
\text { undergraduate students } \\
\text { - Participate in training that provides field directors and } \\
\text { supervisors with skills needed to intervene when inappropriate } \\
\text { behavior occurs } \\
\text { - Require evidence-based student training specifically designed } \\
\text { for undergraduate students prior to the field school }\end{array}$ \\
\hline $\begin{array}{l}\text { Climate and } \\
\text { culture }\end{array}$ & $\begin{array}{l}\text { - Recommendation 1a: Field directors should take } \\
\text { - Recomit steps to achieve gender and racial equity } \\
\text { respectful working environment } \\
\text { - Recommendation 2: Field directors should address } \\
\text { gender harassment } \\
\text { - Recommendation 3: Field directors should move } \\
\text { beyond compliance to address climate and culture } \\
\text { - Recommendation 4a: Field directors should develop } \\
\text { - Recommendation } 4 \text { c: Field directors should implement } \\
\text { - Recomate surveys } \\
\text { - Recommendation 4d: Field directors should consider } \\
\text { inappropriate behavior a breach of research ethics } \\
\text { - Recommendation } 8 \text { : Field directors should measure } \\
\text { progress toward safe environments }\end{array}$ & $\begin{array}{l}\text { - Communicate intention to build a respectful, positive, and civil } \\
\text { - Corking environment among all field school contexts } \\
\text { - Pppropriate and inappropriate behaviors } \\
\text { - envide an example of a positive, civil research and living } \\
\text { - Lead by example by not making or participating in } \\
\text { inappropriate gender, sexual, or racial stories, comments, and/ } \\
\text { or jokes, and immediately stop those behaviors when they occur } \\
\text { - Include a diverse group of teaching assistants } \\
\text { - Implement weekly, formative assessment of climate and culture } \\
\text { - Hold weekly critical reflection sessions facilitated by staff and } \\
\text { students }\end{array}$ \\
\hline $\begin{array}{l}\text { Supervisory } \\
\text { hierarchies }\end{array}$ & $\begin{array}{l}\text { Recommendation 5: Diffuse hierarchical power } \\
\text { structures in which students are dependent on } \\
\text { supervisors }\end{array}$ & $\begin{array}{l}\text { - Create multiple mechanisms, not solely through field director, } \\
\text { for students and staff to report inappropriate behavior, including } \\
\text { providing contact information of field director's supervisors } \\
\text { (chair, dean, etc.) } \\
\text { - Provide contact information for faculty network as a means for } \\
\text { students to report inappropriate behavior } \\
\text { - Develop respectful and egalitarian forms of leadership by } \\
\text { conveying value of all participants } \\
\text { - Share all research and living tasks equally } \\
\text { - Facilitate accommodations so all can learn and participate in } \\
\text { learning activities }\end{array}$ \\
\hline $\begin{array}{l}\text { Reporting } \\
\text { mechanisms }\end{array}$ & $\begin{array}{l}\text { - Recommendation } 4 \mathrm{~b} \text { : Field directors should be } \\
\text { transparent }\end{array}$ & $\begin{array}{l}\text { - Report cases of inappropriate behavior to appropriate offices } \\
\text { fairly and in a timely manner } \\
\text { - Inform all participants how sexual harassment and assault will be } \\
\text { handled, and follow procedures } \\
\text { - Be transparent with students and staff regarding past cases of } \\
\text { sexual harassment and assault and how they were handled }\end{array}$ \\
\hline Support & $\begin{array}{l}\text { Recommendation 6: Field directors should provide } \\
\text { support for targets of harassment }\end{array}$ & $\begin{array}{l}\text { - Encourage students to report any behaviors that seem } \\
\text { inappropriate } \\
\text { - Support students by directing them to the appropriate support } \\
\text { service } \\
\text { - Provide multiple, informal means for targets to report } \\
\text { inappropriate behavior } \\
\text { - Provide mechanisms to remove perpetrator(s) from situations } \\
\text { where they will encounter the target(s) without disrupting } \\
\text { educational opportunities } \\
\text { - Do not allow targets to suffer retaliation for reporting }\end{array}$ \\
\hline
\end{tabular}




\section{Climate and Culture}

As stressed in the NASEM (2018) report, the single most important factor toward preventing sexual harassment and assault in the workplace is creating a workplace climate and culture that does not tolerate sexually inappropriate behavior. Several of the NASEM recommendations center on improving academic climate and culture for women (Table 2). Providing a field school where all students and staff are treated with civility and respect should be a primary goal for field directors. We see multiple ways for field directors to promote such environments.

First and foremost, civil and respectful work environments do not occur accidentally. They are intentionally and actively createdand then modeled and sustained by leadership. Field directors have the same capacity to create a positive learning environment intentionally for students. This can start with setting the explicit expectation that everyone participating in the field school has equal value to add to the experience and will be treated courteously and respectfully. Field directors should also communicate exactly which behaviors will not be tolerated and what the repercussions are if these behaviors occur. Such statements should be communicated directly to students and staff and subsequently modeled by directors. Furthermore, the repercussions of violating expectations must apply to all those involved with the field school, including the director. In cases where students feel that a conversation has veered from civility and appropriateness, students should have a clear way to express their discomfort. Once a student expresses discomfort, field school leadership should guide conversation in another direction in support of that student's wishes. Explicitly and intentionally creating a culture of civility and respect conveys the message that everyone engaged in the field school has value and will be treated as such.

Beyond communicating the value of a positive working environment and intentionally modeling positive behavior, field school directors can also offer students outlets through which to provide feedback on their experiences at field school. This can be in the form of weekly formative surveys where students can anonymously report climate and culture issues, as well as educational content with which they may be struggling. As such, implementing a formative assessment has the potential to help directors become aware of harassment and other behavioral problems while also helping directors facilitate and enhance student learning.

Periodic critical reflection sessions can also provide students with opportunities to voice their concerns. Facilitated time for critical reflections is a teaching tool that enables students to have deeper understanding of the content they have learned by allowing them to reflect on and verbalize these skills (Hatcher and Bringle 1997; Ryan and Ryan 2013). These reflections can also include discussions of which experiences have helped students learn, as well as what students encountered that may have prevented learning. Although critical reflections cannot be conducted anonymously, small group reflections with multiple facilitators may help students communicate behavioral issues they may have experienced or witnessed. Like formative assessment, critical reflection sessions can also be used as a teaching tool to help directors understand concepts students may be struggling with.

A final recommendation to help create a field school climate and culture that promotes safety and inclusion, while conveying intolerance of inappropriate sexual behavior, is to include a diverse group of people among the leadership and staff of the field school. Perceptions of similar situations may differ between two people. With different backgrounds and experiences, one person may perceive an encounter between two students as harmless, whereas another person may sense tension or undertones of disrespect. Working with a diverse population of students and staff allows directors to leverage the experiences of others and call upon a range of perspectives when conflicts arise (Ellemers and Rink 2016).

\section{Supervisory Hierarchies}

The field school learning environment is often structured around supervisory hierarchies with significant power imbalances-one person, often the field director, holds the ultimate authority in the creation of the climate, culture, and learning. With power structures at field schools concentrated with the field director, diffusing this power structure may be a means to help create a field school environment that reduces and prevents sexual harassment and assault.

Doing so requires that directors refocus their leadership organization to one that prioritizes egalitarianism - and that universities and colleges, as well as departments, support field directors in these efforts (NASEM 2018:135). Egalitarian leadership may come in different forms (Flood et al. 2000; Nelson et al. 2017), but generally this leadership values all perspectives, especially those of students, makes those in power intentionally approachable, prioritizes equal sharing in research and living tasks, and makes accommodations that allows everyone to participate (Nelson et al. 2017).

An egalitarian form of leadership requires that those in power create a clear mechanism for those who are not in power to report abuses of power. It may be possible for our discipline to rethink the traditional structure of having a single field director. The advantage of multiple field directors is that they can operate a field school while providing several pathways_or a network-for students to find advice and support, as well as specific person in power to whom students can report issues of inappropriate behavior. Multiple field directors, in addition to graduate students, can work collaboratively in assessing field school applications, assigning fieldwork tasks, and determining final grades. A multiple-director approach may not require all directors to be on site at all times, but it requires collective responsibility in overseeing the climate and culture of the field school and a collective check on the behavior of all staff and supervisors involved.

With recent budget cuts in higher education, diffusing power structures so that other faculty and graduate students have a voice in field school leadership, with associated financial compensation, may be unachievable for many. However, it is important for all of us in field school directorship positions to advocate for practices that support safe and inclusive learning environments for students.

Another mechanism for diffusing power is to have field directors provide contact information of their supervisors, such as a department chair, dean, or provost. This allows students to report any cases of inappropriate behavior or abuses of power directly to those in a position of authority over the field director. The model of field school instruction has traditionally involved power isolation and imbalance, but there are forms of directing that can reallocate 
power structures and create an environment in which all those involved in the field school hold some power in the creation of the climate and culture.

\section{Reporting Mechanisms}

One of the most straightforward ways to prevent sexual harassment at field schools is to develop and disseminate clear, transparent, and consistent anti-harassment policies and then follow through on those policies. Policies should be widely distributed, effortlessly accessed, and easily understood by students and staff (i.e., not written with legal jargon). Policies should also detail the expected consequences for those in violation, as well as the process and expected timeline for investigation and resolution (NASEM 2018:143). All universities and colleges receiving federal funds are required to have structured policies with regard to sexually inappropriate behavior on college campuses, and they will have Title IX coordinators to explain these policies. Field school directors should ensure that students are aware of established university policies, make these policies clear to students, and work with Title IX coordinators if students or staff violate sexual harassment policies. All cases of sexually inappropriate behavior should be reported in a timely manner and to those with the authority to investigate.

\section{Support}

When students and staff do report incidents of sexually inappropriate behavior, they should clearly be supported through the reporting and investigation process. Students, staff, and colleagues often fear reporting given the general perception that those in power within institutions of higher education will do little to respond effectively (Pappas 2016). Furthermore, those who do report often fear reprisal and potential damage to their future educational opportunities and career. Field school directors should be intentional in demonstrating a commitment to support those who do report. Additionally, directors should express their respect for those who report as well as their acknowledgement of the courage it takes to speak up. Bystanders also play a key role in reporting, and they should also be viewed as courageous when they come forward.

It is also important for field school directors to consider reviewing the steps they are taking to ensure a safe and supportive field school with their home institution's Title IX coordinator and other faculty, staff, and students to verify that they are clear and logical. Field school policies and procedures toward sexual harassment and assault should be reviewed and discussed periodically to keep them current and consistent with best practices-and to include stakeholder voices in these policies.

\section{Beyond Field Schools}

The recommendations we present here are aimed toward reducing and preventing sexual harassment and assault in the setting of field schools. Many of the recommendations we provide may also be appropriate for any archaeological fieldwork. Although not the focus of our current research, these recommendations should be considered in the context of cultural resource management. Steps should be taken to investigate how these recommendations impact the workplaces for professional archaeologists.

\section{ADDITIONAL RECOMMENDATIONS TO IMPROVE FIELD SCHOOLS}

In addition to the NASEM (2018) report recommendations, we highlight other measures that may prevent sexual harassment and assault at field schools.

\section{Substance Use and Field Schools}

With respect to field schools where students are living on-site, our discipline should reconsider the access that faculty, staff, and students have to alcohol and other illicit substances-as well as the role that drinking and substance use can play in the culture and climate of the field school. This seems even more pertinent considering that many students who enroll in field schools are under the legal age for alcohol and marijuana use (where recreational marijuana is legal).

Although the NASEM (2018) report gave little attention to the relationship between sexually inappropriate behavior and drug use, others have noted the link between the two, particularly when it comes to alcohol (Bacharach et al. 2007; Carr and VanDeusen 2004; Fedina et al. 2018; Gross et al. 2006; Meyers et al. 2018). Given the known link between substance use and sexually inappropriate behavior as well as the frequency with which sexually inappropriate behavior occurs in the field setting (Clancy et al. 2014; Nelson et al. 2017; VanDerwarker et al. 2018), the discipline must call on field directors to implement alcoholand drug-free field schools among residential programs (Meyers et al. 2018; Porter 2010). Even though alcohol consumption and drug use is often viewed as a field school rite of passage and a component of the culture of archaeology, it is time we reconsider what defines a formative archaeological field school experience.

There are other good reasons to be cognizant of alcohol consumption and drug use in a field school setting. This includes legal issues involving underage drinking, university drinking policies, and the presentation of professionalism and respect to indigenous communities and the local community where fieldwork is conducted (Porter 2010). Field directors should be intentional about providing experiences that support comradery and fellowship among students that do not involve alcohol or drug use.

\section{Support of Archaeological Professional Organizations}

Research clearly demonstrates the critical role that organization leadership plays in developing and sustaining cultural change (Lee 2018; Tenbrunsel et al. 2019). Within the field of archaeology, this leadership extends to archaeological professional organizations. Professional organizations and their leadership set the tone within the discipline and create the expectations that their practitioners will follow (St. John et al. 2016). As such, it is imperative that archaeological professional organizations emphasize the need for field school directors to create a climate and culture where sexual harassment and assault are not tolerated, where predators in the field are not protected, and where targets of sexually inappropriate behavior are supported. Our professional organizations should 
speak boldly to these issues and support uncompromising measures to ensure that field schools are safe learning environments.

Archaeological professional organizations have recently taken the first steps to adopt codes of conduct at conferences and other sponsored activities (Archaeological Institute of America 2018; Society for American Archaeology 2019; Society for Historical Archaeology 2020), and they have explicit statements about safe and supportive learning environments in their principles of professional conduct (American Anthropological Association 2018; Register of Professional Archaeologists 2020; Society for American Archaeology 2016; Society for Historical Archaeology 2020). Furthermore, some regional professional organizations have freely and openly provided suggested templates for field school and field research codes of conduct, training modules, and additional resources to support and sustain safe and inclusive field environments (Southeastern Archaeological Conference 2019). These measures should be applauded. Additional measures should be adopted to strengthen our professional organizations' commitment to fostering a supportive, harassment- and assault-free discipline. Our professional organizations should support the discussion of various evidence-based resources to reduce and prevent sexual harassment and assault, and these resources should be easily accessible to all. These measures may include adopting policies in which sexually inappropriate behavior is considered research misconduct. Professional organizations can also use their influence to highlight field schools that promote safe and inclusive learning. Archaeological professional organizations have made great strides in addressing sexual harassment and assault. They should continue to address issues related to harassment and assault, support research in this area, and provide forums so that the members of the field can continue to discuss ways to improve and thoughtfully respond to problems when they arise.

\section{CONCLUSIONS AND FUTURE DIRECTIONS}

Sexual harassment has been a pervasive issue in higher education, field-based research disciplines, and archaeology for decades (Clancy et al. 2014; Meyers et al. 2018; NASEM 2018; VanDerwarker et al. 2018). Despite this fact, the field of archaeology has taken few systematic steps to ensure that aspiring archaeologists encounter a safe and supportive environment when they undertake their first field-based research experience. Archaeologists need to understand and come to terms with the broad history of sexual harassment and assault within our discipline-how it has shaped our field and how it is maintained and perpetuated. The longer that sexual harassment and assault continues, the more difficult it will be to overcome. With each season, this behavior becomes normalized for a new cohort of students enrolling in and completing a field school. We present the recommendations of the NASEM report (2018) and suggest ways these recommendations can be implemented in the field school setting as a first step for our discipline to build safe and inclusive environments for students. It is imperative for future researchers to investigate if and how field school directors implement these recommendations at their field schools and if these implementations are perceived to be effective by directors, graduate students, and undergraduate students.
In addition, although the NASEM report (2018) clearly makes recommendations to support women in academia, less attention has been given to research that investigates how best to support students of color, students who identify as members of the LGBTQ+ community, students who are diverse learners, and male students. Research suggests that these populations may encounter sexual harassment and sexually inappropriate behavior differently from women (Berdahl and Moore 2006; Blackmore et al. 2016; Brown et al. 2017; Clancy et al. 2017; Gay-Antaki and Liverman 2018; Heath-Stout 2019). We need to consider and research a different set of recommendations to support students who identify with each of these groups.

Archaeology is in a position to make progressive changes to the field that have the potential to impact the next generation of archaeologists positively and lead the sciences in intentionally creating field-based learning environments that are designed to support all learners. Restructuring the field school to prioritize student safety and support the inclusion of diverse students must be the first step toward making these progressive changes.

\section{Acknowledgments}

This article was originally presented at the 76th Annual Meeting of the Southeastern Archaeological Conference. This research was supported by the National Science Foundation Award No. 1937392. We would like to thank Drs. Maureen Meyers and Robbie Ethridge as well as the Southeastern Archaeological Conference Executive Committee and Task Force on Sexual Harassment and Assault for providing comments on portions of this manuscript. Laura Heath-Stout and Elizabeth Hannigan provided us with a copy of their in-press manuscript and allowed us to cite their work. Morgan Tallman, Katrina LaCombe, and Samantha Murphy reviewed earlier versions of this manuscript. Manuel Gomez and Fabiola Silva translated the Spanish abstract. This article benefited greatly from the thoughtful comments and suggestions of the anonymous reviewers. The authors are responsible for all the thoughts, opinions, data, and any errors presented.

\section{Data Availability Statement}

No original data are presented in this article.

\section{REFERENCES CITED}

Aitchison, Kenneth

2004 Supply, Demand and a Failure of Understanding: Addressing the Culture Clash between Archaeologists' Expectations for Training and Employment in "Academia" Versus "Practice." World Archaeology 36:203-219.

American Anthropological Association

2018 AAA Releases Comprehensive Policy on Sexual Harassment and Sexual Assault, Anthropology and Environment Society. Electronic document, http://ae.americananthro.org/aaa-releases-comprehensive-policy-onsexual-harassment-and-sexual-assault/, accessed February 1, 2020.

Archaeological Institute of America

2018 Joint Harassment Policy. Electronic document, https://www. archaeological.org/programs/professionals/annual-meeting/jointharassment-policy/, accessed February 1, 2020.

Aycock, Lauren M., Zahra Hazari, Eric Brewe, Kathryn B. H. Clancy, Theodore Hodapp, and Renee Michelle Goertzen

2019 Sexual Harassment Reported by Undergraduate Female Physicists. 
Physical Review Physics Education Research 15(1). DOI:10.1103/ PhysRevPhysEducRes.15.010121.

Bacharach, Samuel B., Peter A. Bamberger, and Valerie M. McKinney 2007 Harassing under the Influence: The Prevalence of Male Heavy Drinking, the Embeddedness of Permissive Workplace Drinking Norms, and the Gender Harassment of Female Coworkers. Journal of Occupational Health Psychology 12:232-250.

Banyard, Victoria L., Jennifer M. Demers, Ellen S. Cohn, Katie M. Edwards, Mary M. Moynihan, Wendy A. Walsh, and Sally K. Ward

2017 Academic Correlates of Unwanted Sexual Contact, Intercourse, Stalking and Intimate Partner Violence: An Understudied but Important Consequence for College Students. Journal of Interpersonal Violence. DOI:10.1177/0886260517715022

Banyard, Victoria L., Mary M. Moynihan, and Elizabethe G. Plante 2007 Sexual Violence Prevention through Bystander Education: An Experimental Evaluation. Journal of Community Psychology 35:463-481.

Bardolph, Dana N

2014 A Critical Evaluation of Recent Gendered Publishing Trends in American Archaeology. American Antiquity 79:522-540.

Bardolph, Dana N., and Amber M. VanDerwarker

2016 Sociopolitics in Southeastern Archaeology: The Role of Gender in Scholarly Authorship. Southeastern Archaeology 35:175-193.

Barthelemy, Ramón S., Melinda McCormick, and Charles Henderson

2016 Gender Discrimination in Physics and Astronomy: Graduate Student Experiences of Sexism and Gender Microaggressions. Physical Review Physics Education Research 12(2). DOI:10.1103/PhysRevPhysEducRes.12. 020119.

Baxter, Jane Eva

2009 Archaeological Field Schools: A Guide for Teaching in the Field. Routledge, New York.

Berdahl, Jennifer L., and Celia Moore

2006 Workplace Harassment: Double Jeopardy for Minority Women. Journal of Applied Psychology 91:426-436.

Bingham, Shereen G., and Lisa L. Scherer

2001 The Unexpected Effects of a Sexual Harassment Educational Program. Journal of Applied Behavioral Science 37:125-153.

Blackmore, Chelsea, Leslie Drane, Richard Baldwin, and David Ellis

2016 Queering Fieldwork: Difference and Identity in Archaeological Practice. SAA Archaeological Record 16(1):18-23.

Brookes, Stuart

2008 Archaeology in the Field: Enhancing the Role of Fieldwork Training and Teaching. Research in Archaeological Education 1(1):31-45.

Brown, Kirsten R., Edlyn Vallejo Peña, and Susan Rankin

2017 Unwanted Sexual Contact: Students with Autism and Other Disabilities at Greater Risk. Journal of College Student Development 58:771-776.

Brown, Amy L., Maria Testa, and Terri L. Messman-Moore

2009 Psychological Consequences of Sexual Victimization Resulting from Force, Incapacitation, or Verbal Coercion. Violence Against Women 15:898-919.

Carr, Joetta L., and Karen M. VanDeusen

2004 Risk Factors for Male Sexual Aggression on College Campuses. Journal of Family Violence 19:279-289.

Cartrette, David P., and Bethany M. Melroe-Lehrman

2012 Describing Changes in Undergraduate Students' Preconceptions of Research Activities. Research in Science Education 42:1073-1100.

Ceci, Stephen J., and Wendy M. Williams

2011 Understanding Current Causes of Women's Underrepresentation in Science. Proceedings of the National Academy of Sciences of the United States of America 108:3157-3162

Chan, Darius K. S., Suk Yee Chow, Chun Bun Lam, and Shu Fai Cheung 2008 Examining the Job-Related, Psychological, and Physical Outcomes of Workplace Sexual Harassment: A Meta-Analytic Review. Psychology of Women Quarterly 32:362-376.

Clancy, Kathryn B. H., Katharine M. N. Lee, Erica M. Rodgers, and Christina Richey

2017 Double Jeopardy in Astronomy and Planetary Science: Women of Color Face Greater Risks of Gendered and Racial Harassment. Journal of Geophysical Research: Planets 122:1610-1623.
Clancy, Kathryn B. H., Robin G. Nelson, Julienne N. Rutherford, and Katie Hind 2014 Survey of Academic Field Experiences (SAFE): Trainees Report Harassment and Assault. PLoS ONE 9(7). DOI:10.1371/journal.pone. 0102172, accessed March 31, 2019.

Clauset, Aaron, Samuel Arbesman, and Daniel B. Larremore

2015 Systematic Inequality and Hierarchy in Faculty Hiring Networks. Science Advances 1(1). DOI:10.1126/sciadv.1400005.

Coker, Ann L., Patricia G. Cook-Craig, Corrine M. Williams, Bonnie S. Fisher, Emily R. Clear, Lisandra S. Garcia, and Lea M. Hegge

2011 Evaluation of Green Dot: An Active Bystander Intervention to Reduce Sexual Violence on College Campuses. Violence Against Women 17:777-796.

Coker, Ann L., Bonnie S. Fisher, Heather M. Bush, Suzanne C. Swan, Corrine M. Williams, Emily R. Clear, and Sarah DeGue

2015 Evaluation of the Green Dot Bystander Intervention to Reduce Interpersonal Violence among College Students across Three Campuses. Violence Against Women 21:1507-1527.

Colaninno, Carol E.

2019 The Need for Discipline-Based Education Research in Archaeology. Journal of Archaeology and Education 3(7):1-24. Electronic document, https://digitalcommons.library.umaine.edu/jae/vol3/iss7/1, accessed November 15, 2019

Cooper, Jessica, Kristen Jabanoski, and Marlene Kaplan

2019 Exploring Experiential Opportunity Impacts on Undergraduate Outcomes in the Geosciences. Journal of Geoscience Education 67:249-265.

Cortina, Lilia M., Suzanne Swan, Louise F. Fitzgerald, and Craig Waldo 1998 Sexual Harassment and Assault: Chilling the Climate for Women in Academia. Psychology of Women Quarterly 22:419-441.

Diaz-Andreu, Margarita, and Marie Louise Stig Sørensen

1998 Excavating Women: Towards an Engendered History of Archaeology. In Excavating Women: A History of Women in European Archaeology, edited by Margarita and Marie Louise Stig Sørensen, pp. 1-28. Routledge, London.

Dobbin, Frank, and Erin L. Kelly

2007 How to Stop Harassment: Professional Construction of Legal Compliance in Organizations. American Journal of Sociology 112:1203-1243.

Ellemers, Naomi, and Floor Rink

2016 Diversity in Work Groups. Current Opinion in Psychology 11:49-53.

Everill, Paul

2015 Pedagogy and Practice: The Provision and Assessment of Archaeological Fieldwork Training in UK Higher Education. Historic Environment: Policy \& Practice 6:122-141.

Fedina, Lisa, Jennifer Lynne Holmes, and Bethany L. Backes

2018 Campus Sexual Assault: A Systematic Review of Prevalence Research from 2000 to 2015. Trauma, Violence, \& Abuse 19:76-93.

Fitzgerald, Louise F., Michele J. Gelfand, and Fritz Drasgow

1995 Measuring Sexual Harassment: Theoretical and Psychometric Advances. Basic and Applied Social Psychology 17:425-445.

Flaherty, Elizabeth A., Sarah M. Walker, Jennifer H. Forrester, and Merav Ben-David

2017 Effects of Course-Based Undergraduate Research Experiences (CURE) on Wildlife Students. Wildlife Society Bulletin 41:701-711.

Flood, Patrick C., Eithne Hannan, Ken G. Smith, Thomas Turner, Michael A. West, and Jeremy Dawson

2000 Chief Executive Leadership Style, Consensus Decision Making, and Top Management Team Effectiveness. European Journal of Work and Organizational Psychology 9:401-420.

Garvey, Jason C., Laura A. Sanders, and Maureen A. Flint

2017 Generational Perceptions of Campus Climate Among LGBTQ Undergraduates. Journal of College Student Development 58:795-817.

Gay-Antaki, Miriam, and Diana Liverman

2018 Climate for Women in Climate Science: Women Scientists and the Intergovernmental Panel on Climate Change. Proceedings of the National Academy of Sciences of the United States of America 115:2060-2065.

Gifford, Carol A., and Elizabeth A. Morris 1985 Digging for Credit: Early Archaeological Field Schools in the American Southwest. American Antiquity 50:395-411.

Goldstein, Lynne, Barbara Mills, Sarah Herr, and Jo Ellen Burkholder 2017 Society for American Archaeology Task Force on Gender Disparities in 
Archaeological Grant Submissions. Final Report to the National Science Foundation and the Society for American Archaeology. Michigan State University, Department of Anthropology. Electronic Document, http:// saa-gender.anthropology.msu.edu/wp-content/uploads/2017/05/

SAA_TF_Gender_Disparities_Final_17April17.pdf, accessed October 15, 2019

Graham, Mark J., Jennifer Frederick, Angela Byars-Winston, Anne-Barrie Hunter, and Jo Handelsman

2013 Increasing Persistence of College Students in STEM. Science 341 (6153):1455-1456

Gross, Alan M., Andrea Winslett, Miguel Roberts, and Carol L. Gohm

2006 An Examination of Sexual Violence against College Women. Violence Against Women 12:288-300.

Hatcher, Julie A., and Robert G. Bringle

1997 Reflection: Bridging the Gap between Service and Learning. College Teaching 45:153-158.

Hays-Gilpin, Kelley, Meagen Thies-Sauder, Catherine Jalbert, Laura Heath-Stout, and Heather Thaker

2019 Changing Our Professional Culture of Apathy and Creating Safety in Archaeology: Progress Report from the SAA Task Force on Sexual and AntiHarassment Policies and Procedures. SAA Archaeological Record 19(4):8-11.

Heath-Stout, Laura

2019 Diversity, Identity, and Oppression in the Production of Archaeological Knowledge. PhD dissertation, Department of Anthropology, Boston University, Boston.

Heath-Stout, Laura, and Elizabeth M. Hannigan

2020 Affording Archaeology: How Field School Costs Promote Exclusivity. Advances in Archaeological Practice 8. DOI:10.1017/aap.2020.7.

Holland, Kathryn J., Verónica Caridad Rabelo, and Lilia Cortina

2016 See Something, Do Something: Predicting Sexual Assault Bystander Intentions in the US Military. American Journal of Community Psychology 58:3-15.

Jacobson, Susan Kay, Mallory D. McDuff, and Martha C. Monroe

2015 Conservation Education and Outreach Techniques. Oxford University Press, Oxford.

Jalbert, Catherine

2019 Archaeology in Canada: An Analysis of Demographics and Working Conditions in the Discipline. PhD dissertation, Department of Archaeology, Memorial University of Newfoundland, St. John's, Newfoundland, Canada.

Jordan, Carol E., Jessica L. Combs, and Gregory T. Smith

2014 An Exploration of Sexual Victimization and Academic Performance among College Women. Trauma, Violence, \& Abuse 15:191-200.

Kalof, Linda, Kimberly K. Eby, Jennifer L. Matheson, and Rob J. Kroska

2001 The Influence of Race and Gender on Student Self-Reports of Sexual Harassment by College Professors. Gender \& Society 15:282-302.

LeBlanc, Manon Mireille, Julian Barling, and Nick Turner

2014 Intimate Partner Aggression and Women's Work Outcomes. Journal of Occupational Health Psychology 19:399-412.

Lee, Junghyun

2018 Passive Leadership and Sexual Harassment: Roles of Observed Hostility and Workplace Gender Ratio. Personnel Review 47:594-612.

Leskinen, Emily A., Lilia M. Cortina, and Dana B. Kabat

2011 Gender Harassment: Broadening Our Understanding of Sex-Based Harassment at Work. Law and Human Behavior 35:25-39.

Leslie, Sarah-Jane, Andrei Cimpian, Meredith Meyer, and Edward Freeland

2015 Expectations of Brilliance Underlie Gender Distributions across Academic Disciplines. Science 347(6219):262-265.

Lightfoot, Kent G.

2009 Anthropology Field Schools for the 21st Century. General Anthropology 16(1):1-4.

McLaughlin, Heather, Christopher Uggen, and Amy Blackstone

2017 The Economic and Career Effects of Sexual Harassment on Working Women. Gender \& Society 31:333-358.

Meyers, Maureen S., Elizabeth T. Horton, Edmond A. Boudreaux, Stephen B. Carmody, Alice P. Wright, and Victoria G. Dekle

2018 The Context and Consequences of Sexual Harassment in Southeastern Archaeology. Advances in Archaeological Practice 6:275-287.

Mogk, David W., and Charles Goodwin

2012 Learning in the Field: Synthesis of Research on Thinking and Learning in the Geosciences. In Earth and Mind II: A Synthesis of Research on Thinking and Learning in the Geosciences, edited by K. A. Kastens and Cathryn A. Manduca, pp. 131-163. Special Paper 486. Geological Society of America, Boulder, Colorado.

Moser, Stephanie

2007 On Disciplinary Culture: Archaeology as Fieldwork and Its Gendered Associations. Journal of Archaeological Method and Theory 14:235-263.

Moss-Racusin, Corinne A., John F. Dovidio, Victoria L. Brescoll, Mark J. Graham, and Jo Handelsman

2012 Science Faculty's Subtle Gender Biases Favor Male Students.

Proceedings of the National Academy of Sciences of the United States of America 109:16474-16479.

Moyer, Robert S., and Anjan Nath

1998 Some Effects of Brief Training Interventions on Perceptions of Sexual Harassment. Journal of Applied Social Psychology 28:333-356.

Muckle, Robert

2014 On Sexual Harassment and Assault in Archaeology. SAA Archaeological Record 14(5):32-33.

Munge, Brendon, Glyn Thomas, and Deborah Heck

2018 Outdoor Fieldwork in Higher Education: Learning from Multidisciplinary Experience. Journal of Experiential Education 41(1):39-53.

Mytum, Harold

2012 Field Schools: People, Places, and Things in the Present. In Global Perspectives on Archaeological Field Schools: Constructions of Knowledge and Experience, edited by Harold Mytum, pp. 243-249. Springer, New York.

Mytum, Harold (editor)

2012 Global Perspectives on Archaeological Field Schools: Constructions of Knowledge and Experience. Springer, New York.

NASEM (National Academies of Sciences, Engineering, and Medicine)

2018 Sexual Harassment of Women: Climate, Culture, and Consequences in Academic Sciences, Engineering, and Medicine. National Academies Press, Washington, DC.

National Research Council

2014 Enhancing the Value and Sustainability of Field Stations and Marine Laboratories in the 21st Century. National Academies Press, Washington, DC.

Nelson, Robin G., Julienne N. Rutherford, Katie Hinde, and Kathryn B. H. Clancy 2017 Signaling Safety: Characterizing Fieldwork Experiences and Their Implications for Career Trajectories. American Anthropologist 119:710-722.

Pappas, Brian A.

2016 Out from the Shadows: Title IX, University Ombuds, and the Reporting of Campus Sexual Misconduct. Denver Literature Review 94:71.

Perry, Jennifer E.

2004 Authentic Learning in Field Schools: Preparing Future Members of the Archaeological Community. World Archaeology 36:236-260.

Porter, Benjamin W.

2010 Dry Dig: Ethics and Alcohol in Middle Eastern Archaeological Practice. SAA Archaeological Record 10(5):7-11.

Potter, Sharyn, Rebecca Howard, Sharon Murphy, and Mary M. Moynihan 2018 Long-Term Impacts of College Sexual Assaults on Women Survivors' Educational and Career Attainments. Journal of American College Health 66:496-507.

Rankin, Susan R.

2005 Campus Climates for Sexual Minorities. New Directions for Student Services 2005(111):17-23.

Register of Professional Archaeologists

2020 The Register Code: Code of Conduct. Electronic document, https:// rpanet.org/wp-content/uploads/2019/03/Register-Code.pdf, accessed February 1, 2020.

Richards, S. M., K. I. Adsit, and D. M. Ford

2012 Integrating Inquiry-Based Field Investigations into an Environmental Science Curriculum. Journal of the Tennessee Academy of Science 87:105115.

Ryan, Mary, and Michael Ryan

2013 Theorising a Model for Teaching and Assessing Reflective Learning in Higher Education. Higher Education Research \& Development 32:244-257. 
Settles, Isis H., Rachel C. O'Connor, and Stevie C. Y. Yap

2016 Climate Perceptions and Identity Interference among Undergraduate Women in STEM: The Protective Role of Gender Identity. Psychology of Women Quarterly 40:488-503.

Sheppard, Paul R., Brad A. Donaldson, and Gary Huckleberry 2010 Quantitative Assessment of a Field-Based Course on Integrative Geology, Ecology and Cultural History. International Research in Geographical and Environmental Education 19:295-313.

Society for American Archaeology

2016 Principles of Archaeological Ethics. Electronic document, https://www. saa.org/career-practice/ethics-in-professional-archaeology, accessed October 20, 2019.

Society for American Archaeology

2019 Draft SAA Sexual and Anti-Harassment Policies and Procedures. Electronic document, https://archaeology.blob.core.windows.net/ container/docs/default-source/saa-news-and-press-statements/tf-policyintroduction-draft-final-9252019-v2.pdf?sfvrsn=dafb3bb2_2, accessed October 20, 2019.

Society for Historical Archaeology

2020 SHA Sexual Harassment and Discrimination Policy. Electronic document, https://sha.org/about-us/sha-sexual-harassment-discrimination-policy/, accessed February 1, 2020.

Southeastern Archaeological Conference

2019 SEAC Task Force on Sexual Harassment and Assault. Electronic document, https://www.southeasternarchaeology.org/sexual-harassmenttask-force/, accessed October 30, 2019

St. John, Kristen, Eric Riggs, and Dave Mogk

2016 Sexual Harassment in the Sciences: A Call to Geoscience Faculty and Researchers to Respond. Journal of Geoscience Education 64:255-257.

Tenbrunsel, Ann E., McKenzie R. Rees, and Kristina A. Diekmann

2019 Sexual Harassment in Academia: Ethical Climates and Bounded Ethicality. Annual Review of Psychology 70:245-270.
The Collective Change

2019 \#MeToo in Archaeology. SAA Archaeological Record 19(4):12-15

USEEOC (U.S. Equal Employment Opportunity Commission)

2019 Sexual Harassment. Electronic document, https://www.eeoc.gov/laws/ types/sexual_harassment.cfm, accessed May 25, 2019.

VanDerwarker, Amber M., Kaitlin M. Brown, Toni Gonzalez, and Hugh Radde

2018 The UCSB Gender Equity Project: Taking Stock of Mentorship, Equity, and Harassment in California Archaeology through Qualitative Survey Data. California Archaeology 10:131-158.

Walker, Mark, and Dean J. Saitta

2002 Teaching the Craft of Archaeology: Theory, Practice, and the Field School. International Journal of Historical Archaeology 6:199-207.

Whitmeyer, Steven J., and David W. Mogk

2009 Geoscience Field Education: A Recent Resurgence. Eos, Transactions, American Geophysical Union 90:385-386.

\section{AUTHOR INFORMATION}

Carol E. Colaninno Center for STEM Research, Education, and Outreach, Southern Illinois University Edwardsville, Edwardsville, IL 62026, USA (ccolani@ siue.edu, corresponding author)

Shawn P. Lambert $\square$ Department of Anthropology and Middle Eastern Cultures, Mississippi State University, Starkville, MS 39761, USA

Emily L. Beahm $\square$ Arkansas Archeological Survey Winthrop Rockefeller Institute University of Arkansas, Morrilton, AR 72110, USA

Carl G. Drexler $\square$ Arkansas Archeological Survey University of Arkansas, Southern Arkansas University, Magnolia, AR 71753, USA 